\title{
Role of sialylated glycans on bovine lactoferrin against influenza virus
}

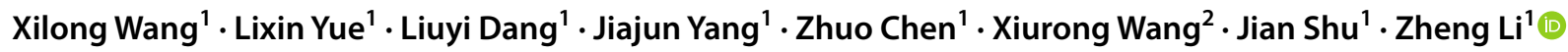

Received: 8 July 2021 / Revised: 8 October 2021 / Accepted: 29 October 2021 / Published online: 15 November 2021

(c) The Author(s), under exclusive licence to Springer Science+Business Media, LLC, part of Springer Nature 2021

\begin{abstract}
Influenza is a worldwide plague caused by the influenza virus (IAV) infection, which is initiated by specific recognition with sialic acids on host cell surface. Bovine lactoferrin (bLf) is a sialoglycoprotein belonging to the transferrin family, and it plays an important role in immune regulation. It also shows toxicity against cancer cells and pathogenic microorganisms including bacteria, fungi, and virus. The purpose of this study is to assess the roles of the sialylated glycans on bLf against IAV. To this end, bLf were first treated with sodium periodate to destroy its sialylated glycans. Then, the binding activity of native or desialylated bLf with various IAV was assessed by blotting assay. Finally, their ability to inhibit IAV attachment to host cells was analyzed in vitro. Our result showed that the sialylated glycans on bLf were almost completely destroyed by sodium periodate treatment. Furthermore, the binding activity of desialylated bLf to IAV and the ability to inhibit IAV mimics binding to MDCK cells were significantly reduced compared to that of native bLf. These results demonstrated that the sialylated glycans on bLf could serve as competitive substrates to block IAV attachment to host cells during the early stages of viral infection. Our findings make an important contribute for the fully understanding of the mechanism of bLf in the prevention of IAV infections and their possible applications in antiviral infection.
\end{abstract}

Keywords Influenza virus $\cdot$ Bovine lactoferrin $\cdot$ Sialylated glycans $\cdot$ Antiviral infection

\section{Introduction}

Influenza is an important cause of morbidity and mortality both in humans and animals caused by IAV infection. The binding of viral coat glycoprotein hemagglutinin (HA) to sialylated glycan receptor on host epithelial cells is a critical step in the infection and transmission of these viruses $[1,2]$. Currently, vaccination and neuraminidase inhibitors are available methods to prevent and treat influenza [3, 4]. However, Influenza vaccines must be updated periodically due to the continuous antigenic drift and sporadic antigenic shift of the viral surface glycoproteins [5]. Unfortunately, the existing vaccines are unable to keep up with the mutation rates of virus [6, 7]. In addition, it also takes several years to develop vaccine for newly emerged viruses. At the same

Zheng Li

zhengli@nwu.edu.cn

1 Laboratory for Functional Glycomics, College of Life Sciences, Northwest University, Xi' an, China

2 National Key Laboratory of Veterinary Biotechnology, Harbin Veterinary Research Institute, Chinese Academy of Agricultural Science, Harbin, China time, the virus is developing resistance to the currently available drugs [8]. Therefore, there are no immediate response drugs to the newly emerging viral outbreaks. In this context, there is an urgently need for the development of novel preventive and therapeutic compounds to control the viral outbreaks.

Attachment of pathogens to the cellular receptor is a prerequisite for most viral infections. Therefore, the use of receptor analogs as inhibitors is a simple antiviral strategy. In the presence of an excessed analogs at viral infection sites, there will be competition between cellular receptors and analogs for binding with viruses and subsequently reduces the interaction between host cell and viruses, thereby reducing the infection [9]. It is well known that IAV uses sialylated glycans on cell surface as a receptor to entry into the host cells. Using this property, studies have demonstrated that the sialylated oligosaccharides could function as influenza hemagglutinin blockers against influenza virus both in vitro and in vivo $[10,11]$.

Bovine lactoferrin (bLf), a nonheme iron-binding glycoprotein with a molecular weight of $80 \mathrm{kDa}$, was discovered in 1937 and isolated in 1960 from bovine milk [12]. It is composed of 696 amino acids that folded into globular carboxyl 
(C) and amino (N) terminal lobes [13]. The two lobes are further divided into two domains ( $\mathrm{C} 1$ and $\mathrm{C} 2, \mathrm{~N} 1$ and $\mathrm{N} 2)$ and each lobe binds one $\mathrm{Fe}(\mathrm{III})$ ion in a deep cleft between two domains. The iron-binding ability is associated with its inhibitory effects on microbial growth and regulation of the motility, aggregation and biofilm formation of pathogenic bacteria [14]. BLf is mainly secreted by epithelial cells and is present in most mucosal secretions, including tears, saliva, vaginal and seminal fluids, nasal and bronchial secretions, and bile and gastric juices [15]. However, its highest concentration was found in milk, especially in colostrum up to $0.8 \mathrm{~g} / \mathrm{L}$ [16].

BLf has shown toxicity against various enveloped and naked viruses such as influenza virus [17], human cytomegalovirus [18], herpes simplex virus 1 and 2 [19, 20], human immunodeficiency virus [18, 21], human hepatitis virus B and C [22, 23], respiratory syncytial virus [24], and newly emerging SARS-CoV-2 [25, 26]. Previous studies have been demonstrated that bLf exerts anti-influenza effects from several aspects. For example, bLf can bind to the HA of influenza virus, therefore preventing the fusion of the viral envelope with the cell membrane [27, 28]. bLf also inhibits IAV induced programmed cell death by interfering with caspase 3 and blocks nuclear export of viral ribonucleoproteins, therefore preventing viral assembly [29]. Moreover, bLf is able to prevent IAV cytopathic effects in desialylated, deglycosylated, apo, and ionsaturated forms [30]. However, the previous studies mainly focused on the late stages of viral infection. As for the roles of the sialylated glycans on bLf in the early stages of viral infection are still not completely clear.

Glycosylation is one of the most common post-translational modification of proteins, and plays an important role in protein's biological function. It has been reported that bLf possess five potential glycosylation sites (Asn233, Asn281, Asn368, Asn476, Asn545), which are mostly exposed on the outer surface of the molecule and may contribute to its antiviral activity [31]. It was reported that the glycosylation of bLf has no effects on the inhibition of influenza virus replication [30]. It is possible that sialylated glycans contribute the antiviral effects of bLf by affecting the early stages of viral infection, which however yet to be explored. In this context, the present study aimed to determine the role of sialylated glycans on bLf in the early phases of influenza viral infection, and help to understand the biological significance of protein sialylation in the prevention of IAV infections and their possible applications in the antiviral infection.

\section{Materials and methods}

\section{IAV preparation and cell culture}

IAV strains including two H5N1 subtypes (A/Chicken/ Guangxi/4/2009 (H5N1 CK), A/Duck/Guangdong/17/2008
(H5N1 DK)), two H5N2 subtypes (A/Mallard/Jiangxi/16/2005 (H5N2 M), A/Ostrich/Denmark/96-72,420/1996 (H5N2 Os)), one H7N1 subtype (A/Fowl/Rostock/45/1934 (H7N1 KP)), and one H7N2 subtype (A/Chicken/Hebei/1/2002 (H7N2 CK)) were kindly gifted by Dr. Xiurong Wang, Harbin Veterinary Research Institute, Chinese Academy of Agricultural Science, Harbin, China. These viruses were cultured in allantoic fluid of 10 days old embryonated hen eggs and then purified on a discontinuous sucrose-density gradient as methods described previously[32, 33]. The MDCK (MadinDarby canine kidney) cells (Cat No. CBP60575, Cobioer Biosciences Co., LTD, Nanjing, China) were cultured in DMEM medium (HyClone, Waltham, MA, USA) containing 10\% (v/v) fetal bovine serum (GIBCO, Grand Island, NY, USA), $100 \mathrm{U} / \mathrm{mL}$ penicillin, and $100 \mu \mathrm{g} / \mathrm{mL}$ streptomycin at $37{ }^{\circ} \mathrm{C}$ under $5 \% \mathrm{CO}_{2}$.

\section{Destruction of the sialylated glycans on bLf}

BLf (Sigma-Aldrich) was treated with $10 \mathrm{mM}$ sodium periodate at $4{ }^{\circ} \mathrm{C}$ for $30 \mathrm{~min}$ to destroy their sialylated glycans [34], the rest of sodium periodate was removed by an Ultra Centrifugal filter (Ultracel-10 k, Millipore Corp., Billerica, MA). After that, $5 \mu \mathrm{g}$ native or desialylated bLf was subjected to $10 \%$ SDS-PAGE and silver nitrate staining or transferred to PVDF membranes. Subsequently, these membranes were blocked with $1 \times$ Carbo-Free Blocking Solution and then incubated with $1 \mu \mathrm{g} \mathrm{mL} \mathrm{m}^{-1}$ of Cy5-labelled SNA or MAL-II (vector labs, Burlingame, CA, USA), Finally, these membranes were scanned by Storm 480 at the wavelength of $635 \mathrm{~nm}$ and further analyzed by Image $\mathrm{J}$ software (ImageJ 1.46r, National Institutes of Health, USA) fluorescence spec-troscopy.

\section{Structure analysis of native and desialylated bLf}

The effect of $\mathrm{NaIO}_{4}$ treatment on the protein structure of bLf was analyzed by fluorescence spectroscopy. Native or desialylated bLf was dissolved in deionized water. The fluorescence spectra of protein solution were recorded in the emission wavelength range from 300 to $600 \mathrm{~nm}$ (5 nm slit), with an excitation wavelength at $290 \mathrm{~nm}$ (5 nm slit) and a photomultiplier tube voltage of $600 \mathrm{~V}$. The data were further analyzed by FL solution software.

\section{Quantification of the sialic acids on native or desialylated bLf}

The sialic acids on native or desialylated bLf were quantified using our previously modified periodate-resorcinol method[35]. In brief, the concentration of native or desialylated bLf were first quantified using the BCA assay, and adjusted to $1 \mathrm{mg} \mathrm{mL}^{-1}$. The bovine fetuin (F3385, 
Sigma-Aldrich) was used as a standard sialoglycoprotein, which was prepared with an initial concentration of $4 \mathrm{mg} \mathrm{mL}^{-1}$ and then serially diluted to $2,1,0.5,0.25,0.125$, $0.0625,0 \mathrm{mg} \mathrm{mL}$. The assay was performed as follows: $100 \mu \mathrm{L}$ of each sample was added to $20 \mu \mathrm{L}$ of $0.04 \mathrm{M}$ sodium periodate solution. The solutions were thoroughly mixed and allowed to stand in a $37^{\circ} \mathrm{C}$ water bath for $60 \mathrm{~min}$. After the addition of $250 \mu \mathrm{L}$ of resorcinol reagent $(0.06 \mathrm{~g}$ resorcinol in a solution containing $6 \mathrm{~mL}$ of $28 \% \mathrm{HCl}, 4 \mathrm{~mL}$ of water, and $25 \mu \mathrm{mol}$ of $\mathrm{CuSO}_{4}$ ), the solutions were mixed, placed in an ice bath for $5 \mathrm{~min}$, heated at $100^{\circ} \mathrm{C}$ for $15 \mathrm{~min}$, cooled to room temperature, and $250 \mu \mathrm{L}$ of tertbutyl alcohol were added. The solutions were mixed vigorously and placed in a $37^{\circ} \mathrm{C}$ water bath for $3 \mathrm{~min}$ to stabilize the color, cooled to room temperature, and the absorbances were determined at $630 \mathrm{~nm}$.

\section{Evaluation of the binding ability of native or desialylated bLf to IAV}

The viral proteins were extracted by an ether/ethanol solution, the protein concentration was quantified by BCA assay. Then, $100 \mu \mathrm{g}$ viral proteins were incubated with $5 \mu \mathrm{L}$ Cy5 dye (GE healthcare, Amersham Biosciences) under gentle shaking at room temperature for $3 \mathrm{~h}$ without light. The $\mathrm{Cy} 5$ labelled proteins were purified by a G- 25 desalt column (GE healthcare) according to the manufacturer's instructions. After that, $5 \mu \mathrm{g}$ native or desialylated bLf was subjected to $10 \%$ SDS-PAGE and transferred to PVDF membranes. Subsequently, these membranes were blocked with $1 \times$ CarboFree Blocking Solution and then parallelly incubated with Cy5-labelled viral proteins $(20 \mu \mathrm{g} / \mathrm{mL}$ in $1 \times$ Carbo-Free Blocking Solution), and Cy5-labeled H1N1 influenza A vaccine (Split Virion, inactivated) (Sinovac Biotech Ltd., Beijing). Finally, these membranes were scanned by Storm 480 and further analyzed by Image $\mathbf{J}$ software.

\section{Assessment of the role of sialylated glycans on bLf to against IAV}

To assess the ability of native or desialylated bLf to against IAV. Maackia amurensis lectin II (MAL-II) and Sambucus nigra lectin (SNA) were used as HA mimics for avian and human IAV, respectively $[35,36]$. The inhibitory effect of native or desialylated bLf on IAV attachment to MDCK cells was evaluated by lectin histochemistry [35]. In brief, the MDCK cells were seed into confocal culture dishes (JingAn Biotechnology Co., Ltd Shanghai China) and cultured in medium until 70-80\% confluence was reached. After washing with PBS and immobilized by $4 \%$ paraformaldehyde, the cells in the dishes were blocked with PBS containing 5\% BSA at room temperature for $1 \mathrm{~h}$. The mixtures comprised $25 \mu \mathrm{g} \mathrm{mL}^{-1}$ of Cy5 labelled lectins (MAL-II or SNA) and
$20 \mu \mathrm{g} \mathrm{mL}^{-1}$ of native or desialylated bLf were added into a parallel set of dishes and incubated without light at $4{ }^{\circ} \mathrm{C}$ overnight. Next, the MDCK cells in the culture dishes were stained by DAPI (Thermo Fisher Scientific, Waltham, MA, USA) and then photographed using a laser scanning confocal microscope (FV 1000, Olympus, Tokyo, Japan) under the merged channels of Cy5 and DAPI. The fluorescent intensity was analyzed by ImageJ software.

\section{Statistical analysis}

Data were expressed as mean \pm SD and analyzed with GraphPad Prism 8 software. Comparations between two groups were measured by $t$-test. One-way ANOVA and postLSD were used to analyze data among three groups.

\section{Results}

\section{Verification of the sialylated glycans on native or desialylated bLf}

To confirm the destructive effect of sodium periodate treatment on the sialylated glycans of bLf, the binding ability of native or desialylated bLf with sialic acid-binding lectins (SNA and MAL-II) was evaluated by blotting assay. The results showed no obviously difference in molecular weight between native bLf and desialylated bLf (Fig. 1A). In addition, $\mathrm{NaIO}_{4}$ treatment did not affect the protein structure of bLf (Fig. 1B). However, the binding ability of desialylated bLf to SNA or MAL-II was significantly decreased compared to that of native bLf (Fig. 1C, 1D). As for the absolute content of the sialic acids on native or desialylated bLf, the sialic acids were quantified by periodate-resorcinol assay. The sialic acid content in native bLf was $0.462 \%$ of the protein compared $0.037 \%$ in the desialylated bLf, (Fig. 1E). These results indicated that the sialylated glycans on bLf were almost completely destroyed by sodium periodate treatment.

\section{Assessment of IAV bound to native or desialylated bLf}

The binding activity of viral proteins extracted from avian IAV and human H1N1 vaccine to native or desialylated bLf were assessed by blotting analysis. The results showed that with the destruction of sialylated glycans on bLf, the binding ability of bLf to the viral proteins of six IAV strains (H5N1 CK, H5N1 DK, H5N2 M, H5N2 Os, H7N1 KP, $\mathrm{H} 7 \mathrm{~N} 2 \mathrm{CK}$ ) as well as the human $\mathrm{H} 1 \mathrm{~N} 1$ vaccine decreased significantly (Fig. 2A). The fluorescence intensity of desialylated bLf bound to IAV or human H1N1 vaccine only retained $37-60 \%$ of that of native bLf (Fig. 2B). These 
Fig. 1 Verification of sialylated glycans on native or desialylated bLf. A Silver nitrate staining. B Fluorescence spectra. C Lectin blotting. Proteins were visualized by Cy5 labeled MAL-II (left) and Cy5 labeled SNA (right). D Gray value analysis. Relative gray values of lectin blotting were analysis from three replications by ImageJ software. E Quantification of sialic acid contents. Sialic acid contents of native or desialylated bLf were quantified and presented as a percentage of protein. M: protein molecular weight markers, lane 1: native bLf, lane 2: desialylated bLf. $* P<0.05, * * P<0.01$, $* * * P<0.001$
A

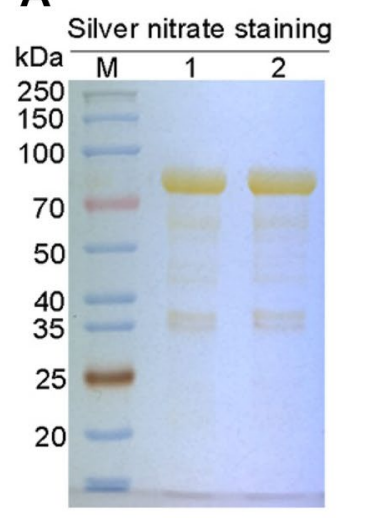

B

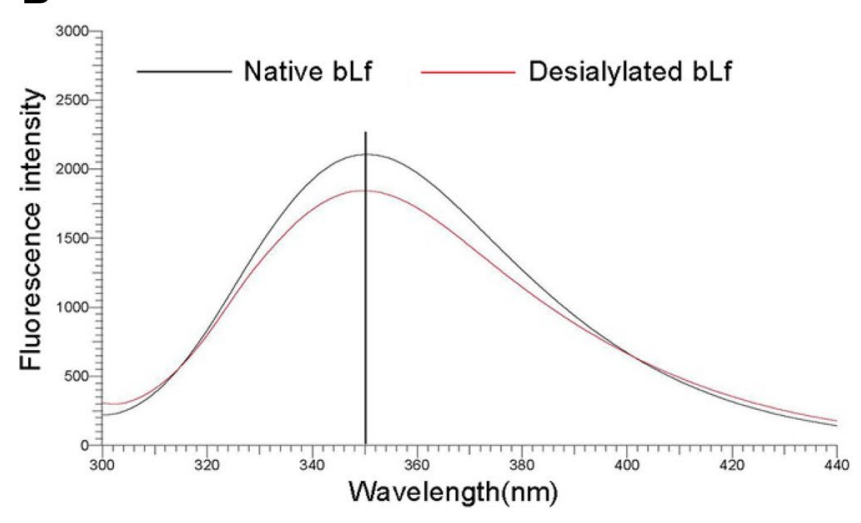

C

Cy5 labeled MAL- II Cy5 labeled SNA
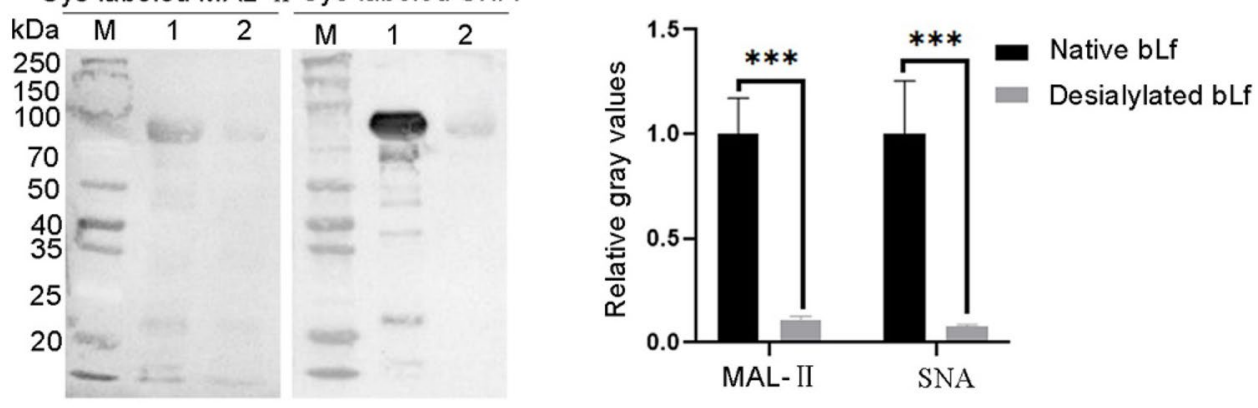

E

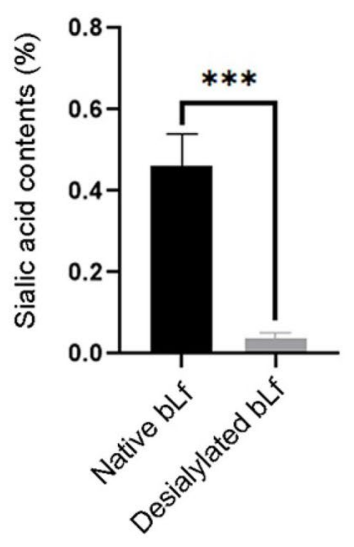

results suggested that the sialylated glycans on bLf is vital for the binding ability of bLf with IAV.

\section{Roles of the sialylated glycans on bLf against IAV}

The ability of native or desialylated bLf to block the attachment of HA mimics to MDCK cells was assessed by lectin histochemistry. As shown in Fig. 3, both MAL-II and SNA could bind efficiently to the surface of MDCK cells (Fig. 3A). Notably, these binding can be inhibited when bLf was present in the system. Furthermore, the inhibitory effect of bLf was more pronounced on SNA than that of MAL-II (Fig. 3B). Interestingly, these inhibitions were reduced when the sialylated glycans of bLf were destroyed (Fig. 3C). The MAL-II and SNA bound to MDCK cells were reduced approximately $40 \%$ and $85 \%$ of the control when native bLf was present in the system. However, with the desialylation, the inhibition ability decreased to only $30 \%$ and $60 \%$ compared with that of control, respectively (Fig. 3D and 3E). These results indicated that the sialylated glycans on bLf could serves as competitive substrates to block IAV attachment to the host cells, therefore reducing the viral infection. 
Fig. 2 Assessing the binding activity of native or desialylated bLf with IAV. A Viral proteins blotting. From left to right: Cy5-labeled viral proteins from H5N1 CK, H5N1 DK, H5N2 Os, H5N2 M, H7N1 KP, H7N2 $\mathrm{CK}$, and $\mathrm{H} 1 \mathrm{~N} 1$ vaccine in turns. B The relative fluorescent intensity of native or desialylated bLf that bind with IAV. The fluorescent intensity in native bLf was deemed as 1 and compared to that of desialylated bLf. Data was measured from three replications by ImageJ software. M: protein molecular weight markers, lane 1: native bLf, lane 2: desialylated bLf. $* P<0.05$, $* * P<0.01, * * * P<0.001$
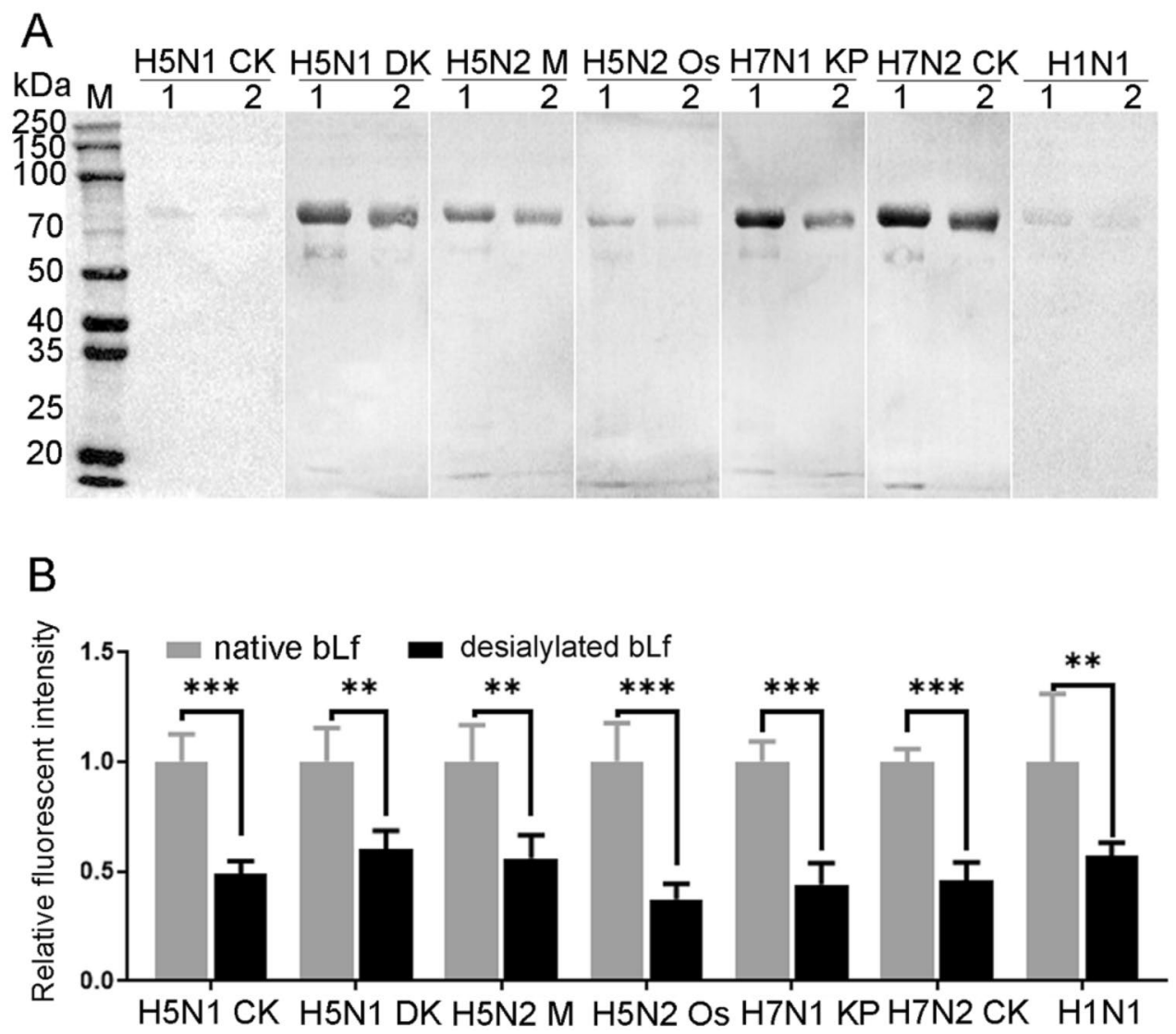

\section{Discussion}

Influenza is an acute respiratory disease in mammals and domestic poultry. About $20 \%$ of children and $5 \%$ of adults worldwide develop symptomatic influenza A or B each year [37]. The IAV infection is initiated by the binding of viral hemagglutinins to sialoglycoconjugates on the host cell surface [38]. Avian IAV preferentially recognizes $\alpha 2,3$-linked sialic acids, whereas human IAV preferentially recognizes $\alpha 2,6$-linked sialic acids [4]. Although vaccination and antiviral drugs are approved to the treatment and prevention of IAV infection, the emergence of resistant strains and the considerable side effects of drugs limit current therapeutic options [39]. Consequently, there is an urgently need to developed a novel preventive and therapeutic compound to control potential viral outbreaks. In addition to IAV, there are many human and animal pathogens including mumps, noro, rota, and DNA tumor viruses utilize sialic acid as a primary receptor to enter into the host cells[40]. In recent years, many studies have reported that sialoglycoconjugates as glycomimetics can be used to block infection by avian and human influenza viruses [10, 11, 41]. Here, we observed that bLf can bind with Cy5 labeled MAL-II and SNA (Fig. 1C), indicating that bLf possesses both $\alpha 2,3$-and $\alpha 2,6$-linked sialic acids. This result provides a reasonable probability of bLf acts as a receptor analogue for IAV and other sialic acid-binding viruses to block the attachment of virus to host cells.
BLf is a multifunctional glycoprotein and plays important roles in prevention of viral infection, such as influenza virus, canine herpesvirus, chikungunya and zika viruses, herpes simplex virus-1, and dengue virus [42-44]. As for the roles of the sialylated glycans on bLf in the early stages of viral infection are still not completely clear. Our results showed that bLf can directly bind with the viral proteins from avian IAV as well as human H1N1 vaccine (Fig. 2A). Moreover, bLf can block the attachment of IAV mimics to MDCK cells. And the inhibitory effect of bLf on SNA binding to MDCK cells was more pronounced than that of MAL-II (Fig. 3B). These may be due to the fact that bLf strongly binds to SNA than to MAL-II (Fig. 1C, 1D). As expected, the binding activity of bLf to viral proteins and inhibition of IAV mimics attachment to MDCK cells were reduced when the sialylated glycans on bLf were destroyed (Fig. 2 and Fig. 3). Although the inhibitory effect of native and desialylated bLf on MAL-II attachment to MDCK cells was not significantly different (Fig. 3C), the binding of Cy5 labelled MAL-II to MDCK cells tended to be enhanced after removal of sialic acids on bLf (Fig. 3D, 62\% vs $71 \%$ of control). Together, our findings indicated that bLf can directly bind to the viral particles through its sialylated glycans at the early stages of viral infection, blocking the attachment of IAV to the host cells and thus reducing the viral infection. 
Fig. 3 Evaluation of the roles of sialylated glycans on bLf against IAV. Histopathologic examination of Cy5 labeled MAL-II and SNA staining performed on MDCK cells. A Control: $25 \mu \mathrm{g} \mathrm{mL}^{-1}$ of Cy5 labeled MAL-II and SNA were incubated with immobilized MDCK cells. B $20 \mu \mathrm{g} \mathrm{mL}^{-1}$ native bLf, C $20 \mu \mathrm{g} \mathrm{mL}^{-1}$ desialylated bLf were added into the incubation solution. The images were acquired under the same conditions for the DAPI merge channel and the Cy5 channel. The relative fluorescent intensity of Cy5 labeled MAL-II D and SNA $\mathbf{E}$ bound to MDCK cells were analyzed by Image J software. The fluorescent intensity in control was deemed as 1 and compared to that of native or desialylated bLf. Data was measured from three replications. $* P<0.05, * * P<0.01$, $* * * P<0.001$

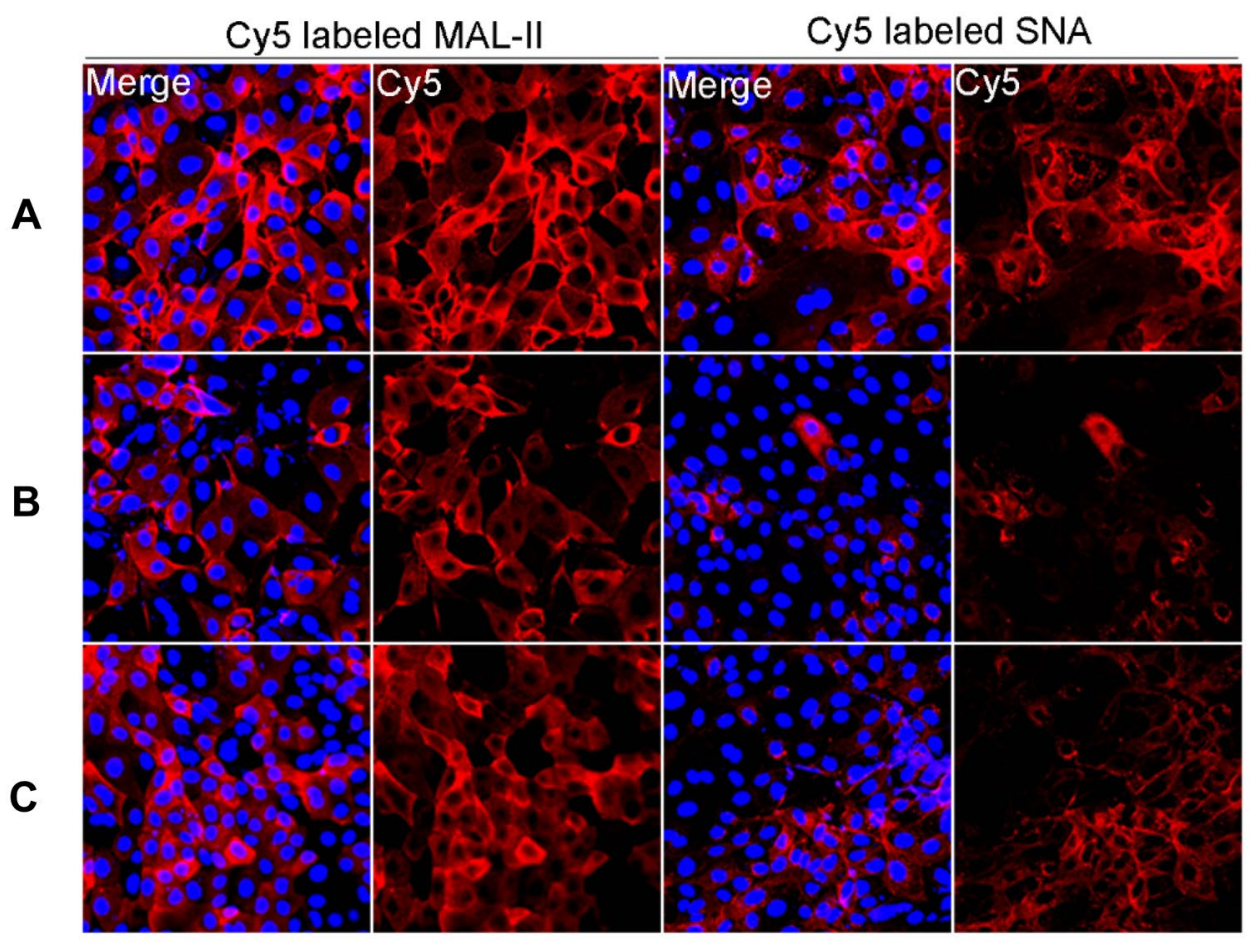

D

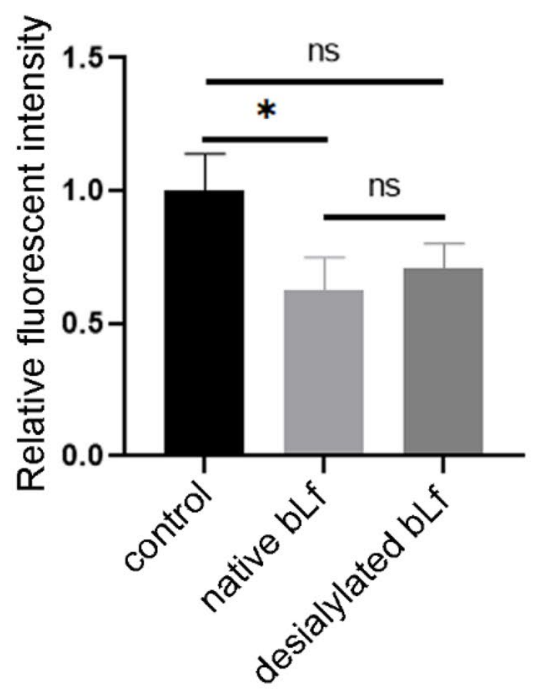

E

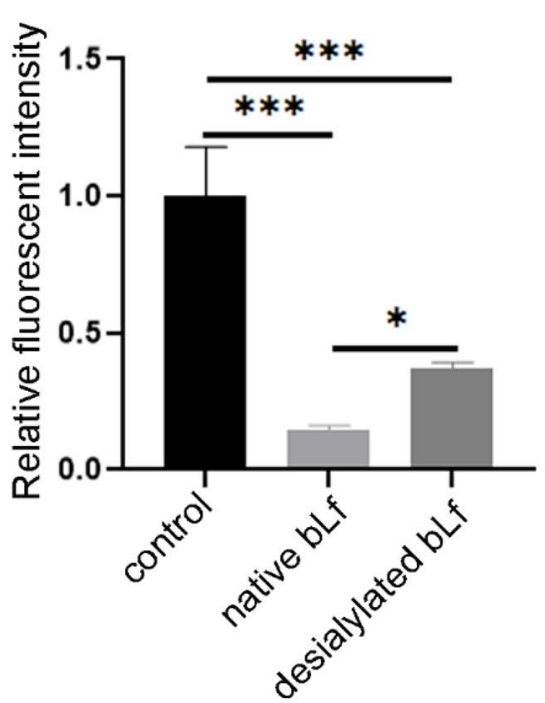

In the present study, the native bLf was first treat with $\mathrm{NaIO}_{4}$ to destroy its sialylated glycans. Subsequently, the sialylated glycans were verified by lectin blotting and quantified by periodate-resorcinol method. Then, the binding ability of native or desialylated bLf to various IAV proteins were evaluated by blotting assay. Finally, the inhibitory effects of native or desialylated bLf on IAV attachment to MDCK cells were assessed by lectin histochemistry. The results showed that the binding ability of desialylated bLf to viral proteins as well as the ability to inhibit the attachment of IAV mimics to MDCK cells were diminished compared to that of native bLf. These results suggested that the sialylated glycans on
bLf could serves as receptor analogs to block IAV attachment to host cells at early stage of viral infection.

\section{Conclusions}

This study provides evidences for the role of sialylated glycans on bLf prevent IAV infection. The sialylated glycans on bLf blocks IAV mimics attachment to MDCK cells at early stage of viral infection. The results provide new insights into the mechanism of bLf against IAV and possible roles of sialoglycoproteins in the anti-viral infection. 
Author contributions Zheng Li conceived and supervised the study. Xilong Wang, Jian Shu designed experiments. Lixin Yue, Jiajun Yang, and Zhuo Chen performed experiments. Xiurong Wang provided reagents. Xilong Wang, Lixin Yue, Liuyi Dang, Zheng Li analyzed data and wrote the manuscript.

Funding This work was supported by grants from the Natural Science Foundation of Shaanxi Province (Grant No. 2021JQ-446).

\section{Declarations}

Ethical approval This article does not contain any studies with human participants or animals performed by any of the authors.

Conflict of interest The authors declare that they have no conflict of interest.

\section{References}

1. Margine, I., Krammer, F.: Animal models for influenza viruses: implications for universal vaccine development. Pathogens 3(4), 845-874 (2014). https://doi.org/10.3390/pathogens3040845

2. Luo, M.: Influenza virus entry. Adv. Exp. Med. Biol. 726, 201221 (2012). https://doi.org/10.1007/978-1-4614-0980-9_9

3. Couch, R.B.: A new antiviral agent for influenza-is there a clinical niche. N. Engl. J. Med. 337(13), 927-928 (1997)

4. Nicholson, K.G., Wood, J.M., Zambon, M.: Influenza. Lancet 362(9397), 1733-1745 (2003)

5. Webster, R.G., Govorkova, E.A.: Continuing challenges in influenza. Ann. N. Y. Acad. Sci. 1323, 115-139 (2014). https://doi.org/ 10.1111 /nyas. 12462

6. Zappa, A., Amendola, A., Romano, L., Zanetti, A.: Emerging and re-emerging viruses in the era of globalisation. Blood transfusion = Trasfusione del sangue 7(3), 167-171 (2009). https://doi.org/ 10.2450/2009.0076-08

7. Howard, C.R., Fletcher, N.F.: Emerging virus diseases: can we ever expect the unexpected? Emerging microbes \& infections 1(12), e46 (2012). https://doi.org/10.1038/emi.2012.47

8. van der Vries, E., Schutten, M., Fraaij, P., Boucher, C., Osterhaus, A.: Influenza virus resistance to antiviral therapy. Adv. Pharmacol. 67, 217-246 (2013). https://doi.org/10.1016/B978-0-12-4058804.00006-8

9. Cozens, D., Read, R.C.: Anti-adhesion methods as novel therapeutics for bacterial infections. Expert Rev. Anti Infect. Ther. 10(12), 1457-1468 (2012)

10. Pandey, R.P., Kim, D.H., Woo, J., Song, J., Jang, S.H., Kim, J.B., Cheong, K.M., Oh, J.S., Sohng, J.K.: Broad-spectrum neutralization of avian influenza viruses by sialylated human milk oligosaccharides: in vivo assessment of 3'-sialyllactose against H9N2 in chickens. Sci. Rep. 8(1), 2563-2575 (2018). https://doi.org/10. 1038/s41598-018-20955-4

11. Oka, H., Onaga, T., Koyama, T., Guo, C.T., Suzuki, Y., Esumi, Y., Hatano, K., Terunuma, D., Matsuoka, K.: Sialyl alpha(2->3) lactose clusters using carbosilane dendrimer core scaffolds as influenza hemagglutinin blockers. Bioorg. Med. Chem. Lett. 18(15), 4405-4408 (2008). https://doi.org/10.1016/j.bmcl.2008.06.101

12. Groves, M.L.: The Isolation of a Red Protein from Milk. J. Am. Chem. Soc. 82(13), 3345-3350 (1960)

13. Wang, B., Timilsena, Y.P., Blanch, E., Adhikari, B.: Lactoferrin: Structure, function, denaturation and digestion. Crit. Rev. Food Sci.
Nutr. 59(4), 580-596 (2019). https://doi.org/10.1080/10408398. 2017.1381583

14. Berlutti, F., Pantanella, F., Natalizi, T., Frioni, A., Paesano, R., Polimeni, A., Valenti, P.: Antiviral properties of lactoferrina natural immunity molecule. Molecules 16(8), 6992-7018 (2011). https://doi.org/10.3390/molecules16086992

15. Rascón-Cruz, Q., Espinoza-Sánchez, E.A., Siqueiros-Cendón, T.S., I.Nakamura-Bencomo, S., Arévalo-Gallegos, S., Iglesias-Figueroa, B.F.: Lactoferrin: A Glycoprotein Involved in Immunomodulation, Anticancer, and Antimicrobial Processes. Molecules 26(1), 205-220 (2021). https://doi.org/10. 3390/molecules26010205

16. Kehoe, S.I., Jayarao, B.M., Heinrichs, A.J.: A survey of bovine colostrum composition and colostrum management practices on Pennsylvania dairy farms. J. Dairy Sci. 90(9), 4108-4116 (2007). https://doi.org/10.3168/jds.2007-0040

17. Yamauchi, K., Wakabayashi, H., Shin, K., Takase, M.: Bovine lactoferrin: benefits and mechanism of action against infections. Biochemistry and cell biology $=$ Biochimie et biologie cellulaire 84(3), 291-296 (2006). https://doi.org/10.1139/o06-054

18. Harmsen, M.C., Swart, P.J., Bethune, M.-P.d., Pauwels, R., Clercq, E.D., The, T.B., Meijer, D.K.F.: Antiviral effects of plasma and milk proteins: lactoferrin shows potent activity against both human immunodeficiency virus and human cytomegalovirus replication in vitro. The Journal of infectious diseases 172(2), 380-388 (1995).

19. Fujihara.T, Hayashi.K: Lactoferrin inhibits herpes simplex virus type-1 (HSV-1) infection to mouse cornea. Archives of virology 140(8), 1469-1472 (1995).

20. Marchetti, M., Trybala, E., Superti, F., Johansson, M., Bergstrom, T.: Inhibition of herpes simplex virus infection by lactoferrin is dependent on interference with the virus binding to glycosaminoglycans. Virology 318(1), 405-413 (2004). https://doi.org/10. 1016/j.virol.2003.09.029

21. Puddu, P., Borghi, P., Gessani, S., Valenti, P., Belardelli, F., Seganti, L.: Antiviral effect of bovine lactoferrin saturated with metal ions on early steps of human immunodeficiency virus type 1 infection. Int. J. Biochem. Cell Biol. 30(9), 1055-1062 (1998)

22. Hara, K., Ikeda, M., Saito, S., Matsumoto, S., Numata, K., Kato, N., Tanaka, K., Sekihar, H.: Lactoferrin inhibits hepatitis B virus infection in cultured human hepatocytes. Hepatol. Res. 24(3), 228-235 (2002)

23. Yi, M., Kaneko, S., Yu, D.Y., Murakami, S.: Hepatitis C Virus Envelope Proteins Bind Lactoferrin. J. Virol. 71(8), 5597-6002 (1997)

24. Sano, H., Nagai, K., Tsutsumi, H., Kuroki, Y.: Lactoferrin and surfactant protein A exhibit distinct binding specificity to $\mathrm{F}$ protein and differently modulate respiratory syncytial virus infection. Eur. J. Immunol. 33(10), 2894-2902 (2003). https:// doi.org/10.1002/eji.200324218

25. Hu, Y., Meng, X., Zhang, F., Xiang, Y., Wang, J.: The in vitro antiviral activity of lactoferrin against common human coronaviruses and SARS-CoV-2 is mediated by targeting the heparan sulfate co-receptor. Emerging microbes \& infections 10(1), 317-330 (2021). https://doi.org/10.1080/22221751.2021.1888660

26. Salaris, C., Scarpa, M., Elli, M., Bertolini, A., Guglielmetti, S., Pregliasco, F., Blandizzi, C., Brun, P., Castagliuolo, I.: Protective Effects of Lactoferrin against SARS-CoV-2 Infection In Vitro. Nutrients 13(2), 328-339 (2021). https://doi.org/10.3390/nu13020328

27. Ammendolia, M.G., Agamennone, M., Pietrantoni, A., Lannutti, F., Siciliano, R.A., De Giulio, B., Amici, C., Superti, F.: Bovine lactoferrin-derived peptides as novel broad-spectrum inhibitors of influenza virus. Pathogens and Global Health 106(1), 12-19 (2013). https://doi.org/10.1179/2047773212y.0000000004 
28. Superti, F., Agamennone, M., Pietrantoni, A., Ammendolia, M.G.: Bovine Lactoferrin Prevents Influenza A Virus Infection by Interfering with the Fusogenic Function of Viral Hemagglutinin. Viruses 11(1) (2019). https://doi.org/10.3390/v11010051

29. Pietrantoni, A., Dofrelli, E., Tinari, A., Ammendolia, M.G., Puzelli, S., Fabiani, C., Donatelli, I., Superti, F.: Bovine lactoferrin inhibits influenza A virus induced programmed cell death in vitro. Biometals : an international journal on the role of metal ions in biology, biochemistry, and medicine 23(3), 465-475 (2010). https://doi.org/10.1007/s10534-010-9323-3

30. Pietrantoni, A., Ammendolia, M.G., Superti, F.: Bovine lactoferrin: involvement of metal saturation and carbohydrates in the inhibition of influenza virus infection. Biochem. Cell Biol. 90(3), 442-448 (2012). https://doi.org/10.1139/o11-072

31. Karav, S., German, J.B., Rouquie, C., Le Parc, A., Barile, D.: Studying Lactoferrin N-Glycosylation. Int. J. Mol. Sci. 18(4), 870-884 (2017). https://doi.org/10.3390/ijms 18040870

32. Reimer, C.B., Baker, R.S., Van Frank, R.M., Newlin, T.E., Cline, G.B., Anderson, N.G.: Purification of Large Quantities of Influenza Virus By Density Gradient Centrifugation. Journal of Virology 1(6), 1207-1216 (1967).

33. Steel, J., Lowen, A.C., Pena, L., Angel, M., Solorzano, A., Albrecht, R., Perez, D.R., Garcia-Sastre, A., Palese, P.: Live attenuated influenza viruses containing NS1 truncations as vaccine candidates against H5N1 highly pathogenic avian influenza. J Virol 83(4), 1742-1753 (2009). https://doi.org/10.1128/JVI.01920-08

34. Kim, D.S., Hosmillo, M., Alfajaro, M.M., Kim, J.Y., Park, J.G., Son, K.Y., Ryu, E.H., Sorgeloos, F., Kwon, H.J., Park, S.J., Lee, W.S., Cho, D., Kwon, J., Choi, J.S., Kang, M.I., Goodfellow, I., Cho, K.O.: Both alpha2,3- and alpha2,6-linked sialic acids on O-linked glycoproteins act as functional receptors for porcine Sapovirus. PLoS Pathog. 10(6), e1004172 (2014). https://doi. org/10.1371/journal.ppat.1004172

35. Wang, X., Ma, T., Yu, H., Chen, Z., Zhu, B., Chen, W., Sun, S., $\mathrm{Li}, \mathrm{Z}$.: Purification of sialoglycoproteins from bovine milk using serotonin-functionalized magnetic particles and their application against influenza A virus. Food Funct. 11(8), 6911-6920 (2020). https://doi.org/10.1039/d0fo01447h

36. Yu, H., Zhong, Y., Zhang, Z., Liu, X., Zhang, K., Zhang, F., Zhang, J., Shu, J., Ding, L., Chen, W., Du, H., Zhang, C., Wang, X., Li, Z.: Characterization of proteins with Siaalpha2-3/6Gallinked glycans from bovine milk and role of their glycans against influenza A virus. Food Funct. 9(10), 5198-5208 (2018). https:// doi.org/10.1039/c8fo00950c
37. Turner, David, A., Wailoo, Allan, J., Nicholson, Karl, G., Cooper, Sutton, Alex, J.: Systematic review and economic decision modelling for the prevention and treatment of influenza A and B. Health Technology Assessment 7(35), iii-iv, xi-xiii, 1-170 (2003).

38. van Riel, D., den Bakker, M.A., Leijten, L.M., Chutinimitkul, S., Munster, V.J., de Wit, E., Rimmelzwaan, G.F., Fouchier, R.A., Osterhaus, A.D., Kuiken, T.: Seasonal and pandemic human influenza viruses attach better to human upper respiratory tract epithelium than avian influenza viruses. Am. J. Pathol. 176(4), 1614-1618 (2010). https://doi.org/10.2353/ajpath.2010.090949

39. Deyde, V.M., Xu, X., Bright, R.A., Shaw, M., Smith, C.B., Zhang, Y., Shu, Y., Gubareva, L.V., Cox, N.J., Klimov, A.I.: Surveillance of resistance to adamantanes among influenza $\mathrm{A}(\mathrm{H} 3 \mathrm{~N} 2)$ and $\mathrm{A}(\mathrm{H} 1 \mathrm{~N} 1)$ viruses isolated worldwide. J. Infect. Dis. 196(2), 249-257 (2007). https://doi.org/10.1086/518936

40. Matrosovich, M., Herrler, G., Klenk, H.D.: Sialic Acid Receptors of Viruses. In: Gerardy-Schahn, R., Delannoy, P., von Itzstein, M. (eds.) SialoGlyco Chemistry and Biology II: Tools and Techniques to Identify and Capture Sialoglycans, pp. 1-28. Springer International Publishing, Cham (2015)

41. Ogata, M., Hidari, K.I.P.J., Murata, T., Shimada, S., Kozaki, W., Park, E.Y., Suzuki, T., Usui, T.: Chemoenzymatic Synthesis of Sialoglycopolypeptides As Glycomimetics to Block Infection by Avian and Human Influenza Viruses. Bioconjug. Chem. 20(3), 538-549 (2009)

42. Carvalho, C.A.M., Casseb, S.M.M., Goncalves, R.B., Silva, E.V.P., Gomes, A.M.O., Vasconcelos, P.F.C.: Bovine lactoferrin activity against Chikungunya and Zika viruses. J. Gen. Virol. 98(7), 1749-1754 (2017). https://doi.org/10.1099/jgv.0.000849

43. Marr, A.K., Jenssen, H., Moniri, M.R., Hancock, R.E., Pante, N.: Bovine lactoferrin and lactoferricin interfere with intracellular trafficking of Herpes simplex virus-1. Biochimie 91(1), 160-164 (2009). https://doi.org/10.1016/j.biochi.2008.05.016

44. Chen, J.M., Fan, Y.C., Lin, J.W., Chen, Y.Y., Hsu, W.L., Chiou, S.S.: Bovine Lactoferrin Inhibits Dengue Virus Infectivity by Interacting with Heparan Sulfate, Low-Density Lipoprotein Receptor, and DC-SIGN. Int. J. Mol. Sci. 18(9), 1957-1969 (2017). https://doi.org/10.3390/ijms 18091957

Publisher's Note Springer Nature remains neutral with regard to jurisdictional claims in published maps and institutional affiliations. 